\title{
A rapid flood inundation model in the floodplain area due to an extreme rainfall event
}

\author{
Indah Salsabiela ${ }^{1}$, Kuswantoro Marko ${ }^{1 *}$, Mangapul P. Tambunan ${ }^{1}$, and Faris Zulkarnain ${ }^{1}$ \\ ${ }^{1}$ Department of Geography, University of Indonesia, Depok 16424, West Java, Indonesia
}

\begin{abstract}
Extreme rainfall in East Jakarta on February 19, 2021 caused flooding in a number of subdistricts. The research was conducted in the central part of Kali Sunter, which flows through three subdistricts, namely Cipinang Melayu, Cipinang Muara, and Pondok Bambu. The purpose of the study was to do flood hazard modeling and analyze the characteristics of flood-affected areas based on land use and topography. Inundation and flood hazard maps is done by: calculating the flood discharge using the SCS-CN method, flood inundation modelling using HEC-RAS, and analyzing the characteristics of the inundated area. This combination is effective for rapid modeling during extreme rainfall events. Based on the research, the distribution of the highest flood hazard area is in RW 004 Cipinang Melayu, with the widest inundation affecting small and medium-sized houses. The characteristics of the affected area are that there is green and empty land which reduces the potential for water to inundate buildings or other land uses. Buildings located in low-hazard housing areas tend to be more organized and relatively medium to large in size. While the types of housing in the Cipinang Melayu with a high level of danger tend to be dense and small to medium in size, but the majority have two floors as a form of flood adaptation.
\end{abstract}

\section{Introduction}

Flooding is one of the major natural disasters that could create severe catastrophic impacts for population, infrastructure, economy, and environment [1-4]. Developing countries are likely to be more prone to flooding considering lower incomes, more housing facilities below standard, and lack of warning systems and preparedness [5]. Extreme and heavy rainfalls happened in Jakarta because of various environmental and climatic conditions $[4,7]$. Causes of the floods in Jakarta are mainly because of heavy rainfall, strongly supported by climate change [7]. Climate change plays a role in changing the cycle of hydrology by affecting precipitation, soil moisture, surface runoff, and the recharge rates of groundwater [6]. In developing countries such as Indonesia, hydrological balance is also disrupted by other factors such as rapid growth of settlements and urbanization which makes the increasing amount of population in cities [8]. Jakarta is also facing another major challenge which is land subsidence. Flooding usually occurs in a relatively high rate of land subsidence areas, and could somehow affect the flooding in both inland and coastal areas $[9,10]$. Subsidence within inland areas usually occurs near the ${ }^{1}$ river, and along with river canal changes and malfunction of the flow system, it will cause riverine flooding aggravation [9].

The study was held in the middle part of Sunter River, which flows through three sub-districts in East
Jakarta, namely Cipinang Melayu of Makasar District, Cipinang Muara of Jatinegara District, and Pondok Bambu in Duren Sawit District. As of 19 February 2021, some parts of East Jakarta, was heavily flooded because of extreme rainfall event. Land use/land cover change (LUCC) in the city is causing the reduction of reservoir areas, which will escalate flood hazard in distinctive places [11]. Rapid development consequently changing the former land use into built-up areas for industrial, residential, and commercial purposes. This expansion and intensification caused by urbanization, added by the topographic condition where most of the areas are floodplains, will result in an infrastructure deficiency which includes flood control. The most affected people are the ones in lowland, from human settlement to livelihood areas [4]. Therefore, it is urgently needed to do flood hazard analysis rapidly in order to help rescue the affected areas through spatial modelling [1]. Flood risk mitigation plans should consider both land use change and land subsidence [12]. One of the products of flood modelling is the inundation map, which is an important tool that can be used by many stakeholders and policymakers to make emergency decisions and plans.

In this study, HEC-RAS is a hydraulic modelling used to produce micro-scaled flood inundation maps effectively. The integration between GIS and HEC-RAS Model makes it easier to produce the maps and count the flood discharge. This study is aimed to find out the potential extension and depth of impacted areas by

\footnotetext{
* Corresponding author: kuswantoro@sci.ui.ac.id
} 
modeling the distribution of flood hazard areas and analyze the characteristics of flood-affected areas based on land use and topography. Another purpose of this study is to help produce flood hazard maps within floodplain areas to measure the hazard and potential risk in the future.

\section{Methods}

\subsection{Study Area}

This research is conducted in the middle part of Sunter River segmentation, which includes a river length of $5.56 \mathrm{~km}$ with an area of $5 \mathrm{~km}^{2}$. The topography of Sunter River as a whole has a height difference of $108.5 \mathrm{~m}$, with maximum height of $120 \mathrm{~m}$ and minimum height of 11.5 $\mathrm{m}$. Sunter River is one of thirteen rivers that flows through Jakarta. Located in $6^{\circ} 10^{\prime}-6^{\circ} 22^{\prime}$ LS dan $106^{\circ}$ $51^{\prime}-106^{\circ} 55^{\prime}$ BT with $36,6 \mathrm{~km}$ long and the area of 76 $\mathrm{km}^{2}$, the upper stream of Sunter River is located in Tapos, Depok, West Java, and ends in Koja, North Jakarta and run through sub-districts, such as Cipinang Melayu, Pondok Bambu, and Cipinang Muara. The surface elevation ranges from $0-34.58 \mathrm{~m}$ with the slope of $0.3 \%$. Sunter River generally has 8 tributaries with the type of bird's-feather watershed, shown in Figure 1. The width of Sunter River ranges from 3-10 m, and is considered as a small river.
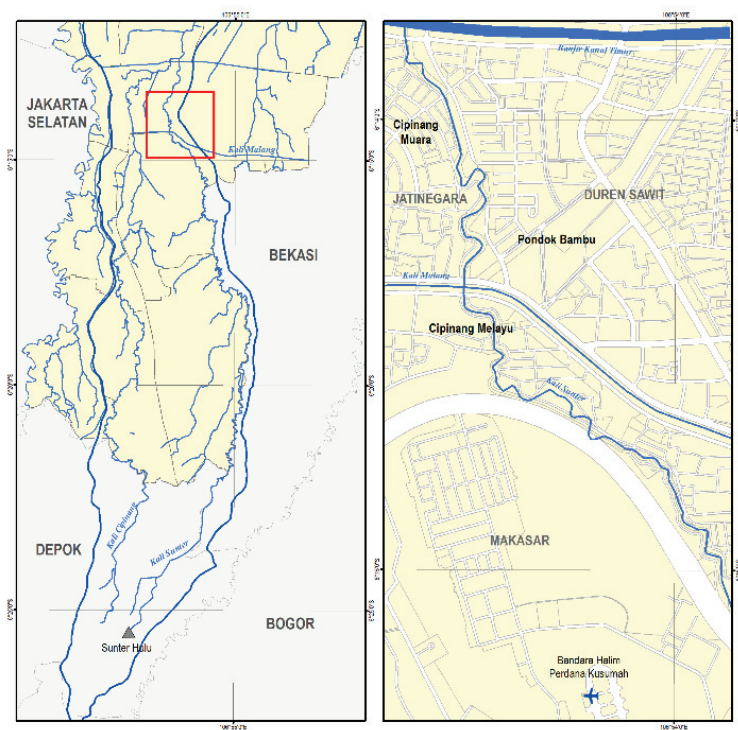

Fig. 1. Study Area and Upper-stream.

This river went through normalization in 2011, meaning it has been designed for the betterment of the channel condition through fixing the river bank and the dimension [13]. Normalization was meant to provide enough river flow capacity to keep the water flowing from the upstream, especially during extreme weather and intense rainfall capacity. Other benefits are to prevent the banks or cliffs from erosion, as well as to return back to the initial river profile to help mitigate the flood.

Generally, the climate of DKI Jakarta is influenced by monsoons with dry season period from June to September and rainy season period from November to March. In this study area, rainfall with high intensity tends to occur from January to March, with the peak intensity in February, as seen on Fig. 2. This happens because February is in the Equator thermal line or the intertropical convergence area. Therefore, the evaporation rate raises as temperature increased, which then causes intense and heavy rains. Observations of climate elements are carried out by the Meteorology, Climatology and Geophysics Agency (BMKG) which include observations of air temperature, humidity, wind speed, air pressure, amount of rainfall and number of rainy days. DKI Jakarta Province has two climate monitoring stations, including: the Kemayoran Meteorological Station in Central Jakarta and the Tanjung Priok Meteorological Station in North Jakarta. According to the BMKG in the 2020 Jakarta Statistics book, DKI Jakarta Province is one of the cities in Indonesia with high temperatures, which generally reaches $35.6^{\circ} \mathrm{C}$ at the maximum value and $24^{\circ} \mathrm{C}$ at the minimum value with an average humidity of $77.7 \%$ at Kemayoran Station and $75.5 \%$ at Tanjung Priok Station.

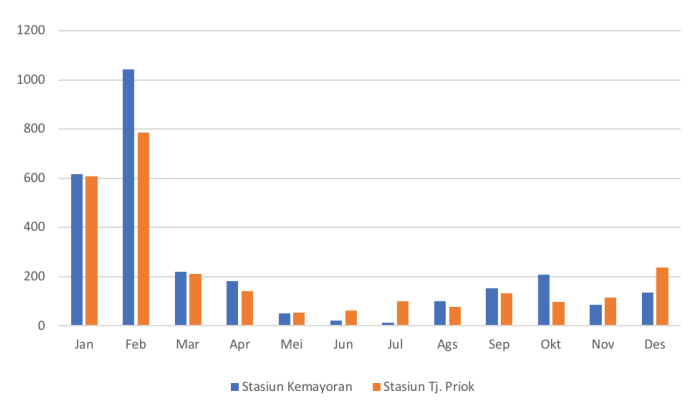

Fig. 2. Rainfall data in Jakarta, 2020.

History of floods in Jakarta has been going on for a long time, but there are three flood phenomena that are among the worst floods happened in the last two decades, which are in 1996, 2002, and 2007 [14]. The flood was classified as severe, both on a regional and national scale, due to its impacts to the wellbeing and mortality. Rainfall data used in this study is rain data when a flood occurs on 19 February 2021, aiming to calculate efficiently. Rain data were obtained from the BMKG Station and Jakarta Flood Monitor. Data verification is done by observing the nearest rain station that represents the research area and with good data conditions.

According to the UN World Population Prospects in Macrotrends, population growth rate in Jakarta has increased over the past decade [15]. In 2011, the population rate was $1.11 \%$ and in 2021 , it is now $1.35 \%$. Land use change keeps increasing because of the development in the city, such as build-up areas, specifically residential areas, industrial areas, and 
commercial areas. This condition could potentially harm the people who are living near the floodplain, or the ones who reside within the lower stream area.

During the calculation of major floods, land use is a very influential factor on surface water runoff. Fluvial landforms have the potential as an area that is prone to flooding. These vulnerable areas are not necessarily affected by flooding, depending on several other triggers such as land use change. The majority of land use within the study area is built-up area, while the area of wet land or water bodies relatively less or decreased.

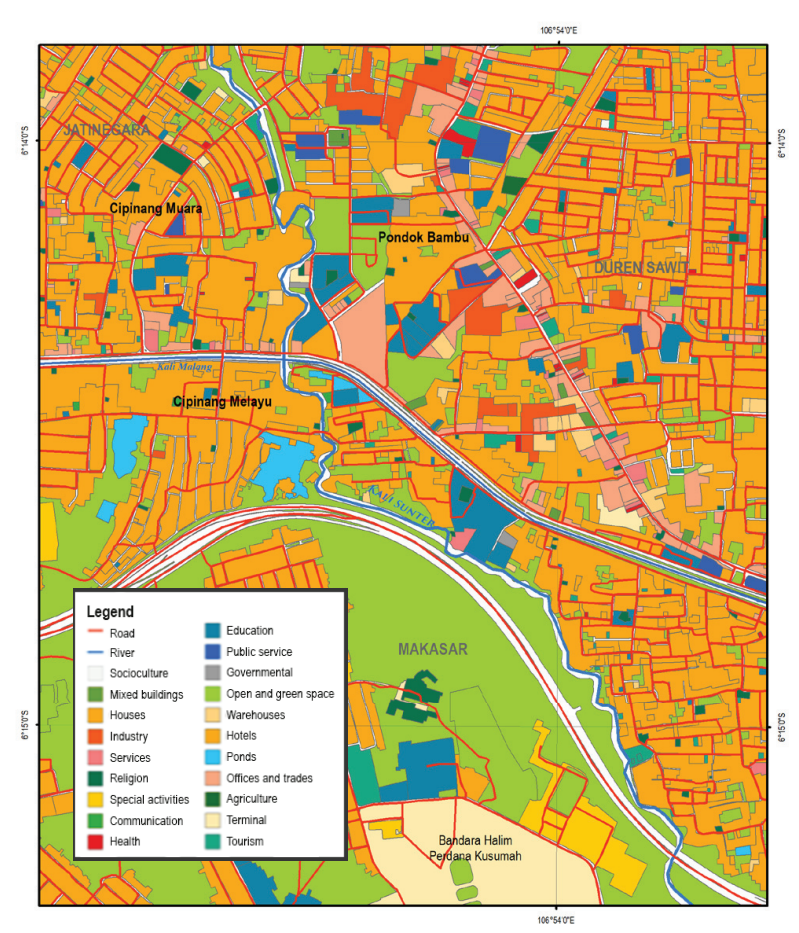

Fig. 3. Land use of the study area.

There are 21 types of land use for the research area on a scale of $1: 13,500$, as seen on Table 1 .

Table 1. Land use type per subdistricts.

\begin{tabular}{|l|l|l|l|}
\hline \multicolumn{1}{|c|}{ Types of Land Use } & $\begin{array}{c}\text { Cupinang } \\
\text { Muara }\end{array}$ & $\begin{array}{c}\text { Cipinang } \\
\text { Melayu }\end{array}$ & $\begin{array}{c}\text { Pondok } \\
\text { Bambu }\end{array}$ \\
\hline Socio-culture & 4 & - & 1 \\
\hline Mixed buildings & - & 7 & 20 \\
\hline Houses & 235 & 369 & 497 \\
\hline Industry & 1 & 2 & 19 \\
\hline Services & 14 & 32 & 45 \\
\hline Religion & 25 & 37 & 40 \\
\hline Special activities & - & 7 & - \\
\hline Others & - & 5 & 3 \\
\hline Health & 11 & 6 & 21 \\
\hline Education & 24 & 31 & 39 \\
\hline Public services & 8 & 2 & 13 \\
\hline Government & 1 & 2 & 5 \\
\hline Vegetation and open space & 91 & 146 & 197 \\
\hline Warehouses & 8 & 7 & 25 \\
\hline Hotels & - & 1 & 1 \\
\hline Ponds & - & 5 & 1 \\
\hline Offices and trades & 39 & 47 & 147 \\
\hline Agriculture & - & - & 1 \\
\hline Terminal & 6 & 7 & 4 \\
\hline Tourism & 17 & 48 & 46 \\
\hline
\end{tabular}

The upper-stream part of the Sunter River has 7 types of land use on a scale of 1:125,000, as shown in Figure 4. The land uses include: lakes/situ, jungle forests, domestic airports, plantations/gardens, settlements, rice fields, and fields/fields. In this map scale, it is also found that the dominance of the land use is housing and settlements. Hulu Kali Sunter is a field or golf course with surrounding settlements. Hulu Kali Sunter is located on a higher ground, namely in Tapos District, Depok City, West Java, along the border between East Jakarta City and Bekasi City.

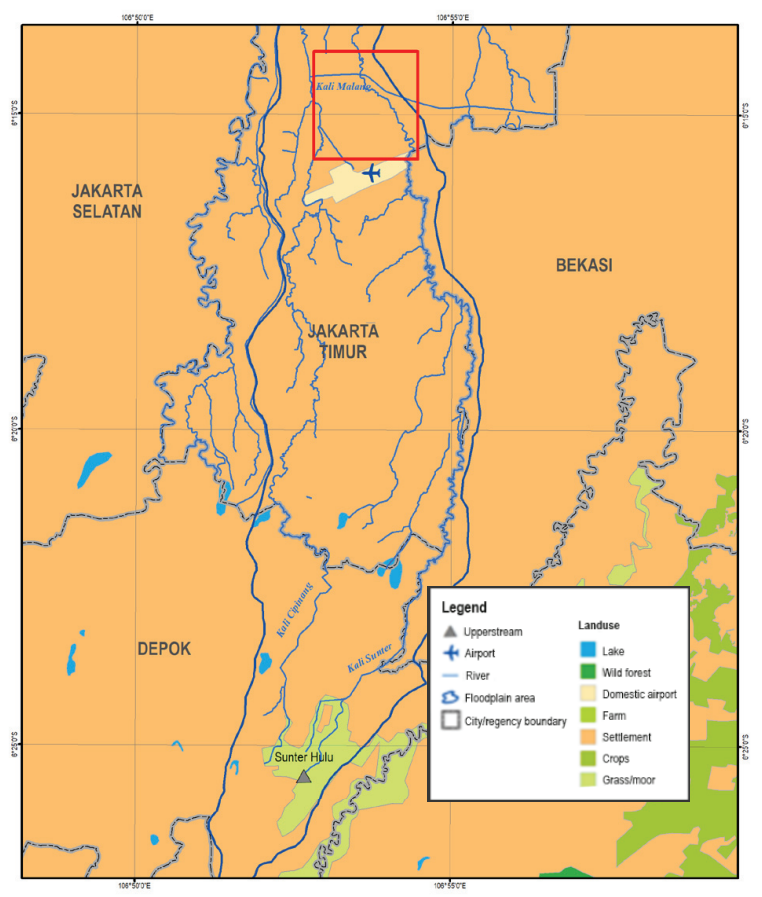

Fig. 4. Land use of the Upper-stream area.

Along the upstream to the study area, the type of soil around Kali Sunter is dominated by volcanic plains. In general, the rock structure in DKI Jakarta is clay and is a quaternary volcanic deposit. Soil texture is used to consider HSG.

Table 2. Soil hydrological classification based on USDA.

\begin{tabular}{|l|l|l|l|l|}
\hline $\begin{array}{c}\text { Group potential when } \\
\text { wet }\end{array}$ & Infiltration & \multicolumn{1}{|c|}{ Soil Type } & \multicolumn{1}{|c|}{ Soil Texture } \\
\hline A & Low & High & $\begin{array}{l}\text { Sandy soil, } \\
\text { gravel }\end{array}$ & $\begin{array}{l}\text { Sand, clay sand, sandy } \\
\text { loam }\end{array}$ \\
\hline B & Semi-low & Medium & $\begin{array}{l}\text { Medium grain } \\
\text { soil }\end{array}$ & Silt, clay \\
\hline C & Semi-high & Slow & $\begin{array}{l}\text { Medium-fine } \\
\text { grained soil }\end{array}$ & Sandy clay \\
\hline D & High & Very slow & $\begin{array}{l}\text { Clay with high } \\
\text { swellability, soil } \\
\text { with high Clay (assorted) } \\
\text { permanent water } \\
\text { table, clay soil }\end{array}$ \\
\hline
\end{tabular}




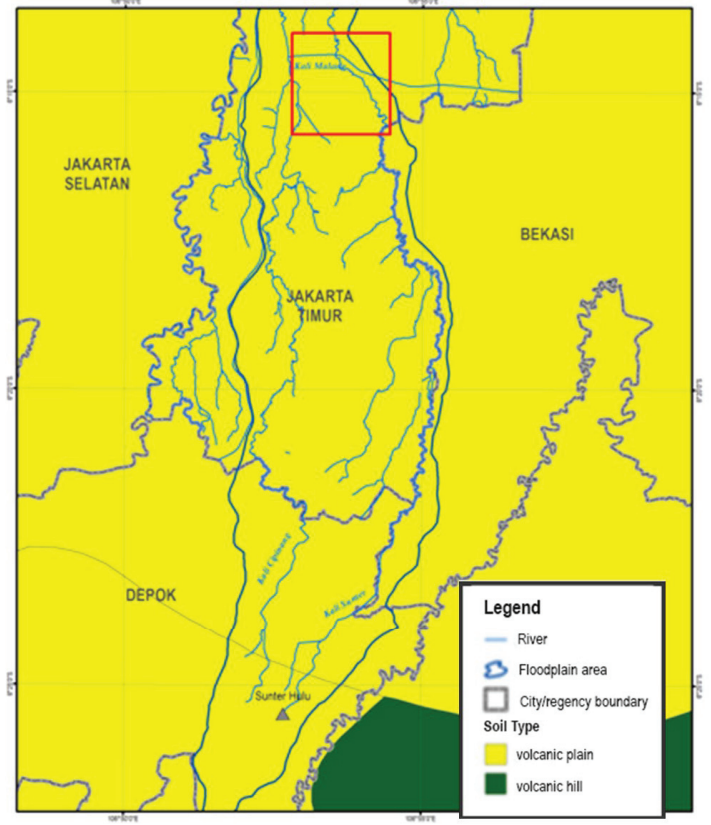

Fig. 5. Soil type of the Upper-stream area.

\subsection{Hydraulic and Flood Modelling}

In this study, hydraulic modelling is implemented to help evaluate the importance of surface flow, such as for forecasting and producing inundation maps. The software that is used is HEC-RAS version 5.0.1, a product of the US Army Corps. of Engineers Hydrologic Engineering Center for River Analysis System, as a tool to model and perform one-dimensional hydraulic calculations in a natural and constructed channel network, for 1D steady and 1D or 2D unsteady flow. In this study, 1D steady flow simulation is used to model the system that is intended to calculate water surface profiles which can handle a single river reach. This software was chosen due to its effectiveness and capability of modelling mixed flow regime water surface profiles.

HEC-RAS is an integrated and interactive software with graphical user interface (GUI) to separate analysis, data storage and management, graphics, and other facilities. It can be used for multi-tasking and multi-user network environments. There are four hydraulic analysis components in the system, including: steadyflow water surface profile; 1D and 2D unsteady-flow simulations; sediment transport computations; and water temperature transport modelling [15]. Steady flow simulation is used in this study, with special features and parameters for steady flow components, such as: obstructions, bridges, culverts, weirs, spillways, levees, and other structures within the floodplain can be considered in the computations. The steady flow simulation is designed for further evaluation in the study of floodplain management and flood control.
HEC-GeoRAS is an integrated extension tool to support using HEC-RAS in ArcGIS, targeted for geographers and planners because it combines engineering and GIS. This study uses HEC-GeoRAS version 10.5 suitable for ArcMap version 10.5.1. Some benefits of using HEC-GeoRAS are: having spatial links when inputting data, doing hydraulic modelling, and mapping floodplain or inundation; utilizing detailed topographic information; able to identify basin areas and the interactions effectively. Combining HEC-RAS and GIS improves modelling efficiency and produces a better and more accurate visual in the results.

\subsection{Flood Discharge Calculation}

Flood discharge is calculated by rainfall-runoff depth and curve number with the method known as Soil Conservation Service Curve Number (SCS-CN) by the U.S. Department of Agriculture. This method is one of the most popular methods to calculate the volume of surface runoff in urban watersheds with a certain amount of rainfall because it is easily applicable, accessible, stable, and useful for ungauged watersheds [16]. The parameters for the curve number are: soilvegetation-land use (SVL) complex; hydrologic condition; antecedent moisture condition; and climate of the watershed. The total of rainfall precipitation $(P)$ with the potential of soil retention $(S)$ are divided into runoff discharge $(Q)$ and initial abstraction (Ia) with the equation as follows.

$$
Q=\frac{\left(P-I_{a}\right)^{2}}{\left(P-I_{a}\right)+S}
$$

To calculate the depth of excess rainfall, initial abstraction correlation value is obtained with Equation 2 and to calculate antecedent moisture condition, $\mathrm{S}$ refers to Equation 3 with the conversion from inch to $\mathrm{mm}$.

$$
\begin{gathered}
I_{a}=0.2 S \\
S=25.4\left(\frac{1000}{\mathrm{CN}}-10\right)
\end{gathered}
$$

In this study, the soil type belongs to Group D, according to the Hydrologic Soil Group. Group D soils have a low infiltration rate when thoroughly wetted, from $0.05-0.15 \mathrm{inch} /$ hour. The soils mainly contain a constraint layer that limits the downward movement of water. The textures are usually clay loams, shallow sandy loam, and soils low in organic content, which indicate a slow rate of water transmission. Urban lands tend to have low permeability and the characteristics of the watersheds area and its surroundings are residential areas, commercial areas, and roads. Hydrologic condition depends on how much vegetation covers the land. A good hydrologic condition allows more infiltration than a poor hydrologic condition because it helps protect the watershed from erosion for the purpose of soil conservation. The initial abstraction consists of interception, surface detention, evaporation, and 
infiltration [16]. The relation between rainfall intensity and time duration is that the more intense the rainfall, the lesser will be the time duration, and it applies alternatively.

\subsection{Flood Inundation Mapping}

It requires three main steps to do the inundation mapping, which include: pre-processing using HECGeoRAS, HEC-RAS to process the exported data from ArcMap, and post-processing to map flood inundation areas [17].

The data required are: digital elevation model (DEM) with $10 \times 10 \mathrm{~m}$ spatial resolution to create triangular irregular network (TIN) and a satellite image of the study area sourced from Google Earth and taken through SAS Planet. The required parameters to process hydraulic models in HEC-RAS are: stream centerline, main channel banks, cross-section lines, which are called channel geometry. A total of 19 cross sections were taken over the single reach modelled as seen in Figure 6.

Pre-processing requires DEM and a satellite image to facilitate the river geometry digitization process using the HEC-GeoRAS extension in ArcMap. The layers of geometry required are: river stream centerlines, riverbank lines, cross-sectional cut lines, flow path centerlines. Other geometry layers are considered optional, such as: bridges/culverts, ineffective flow areas, blocked obstructions, land use, levee, inline structures, and lateral structures layer. The collected geometry files were exported to the HEC-RAS model to edit the geometry per cross-sections, determine the discharge flow, and generate the steady flow simulation and water surface profiles. The files are exported back to ArcMap to visualize flood inundation maps and later to analyze and determine the affected area and area at risk.

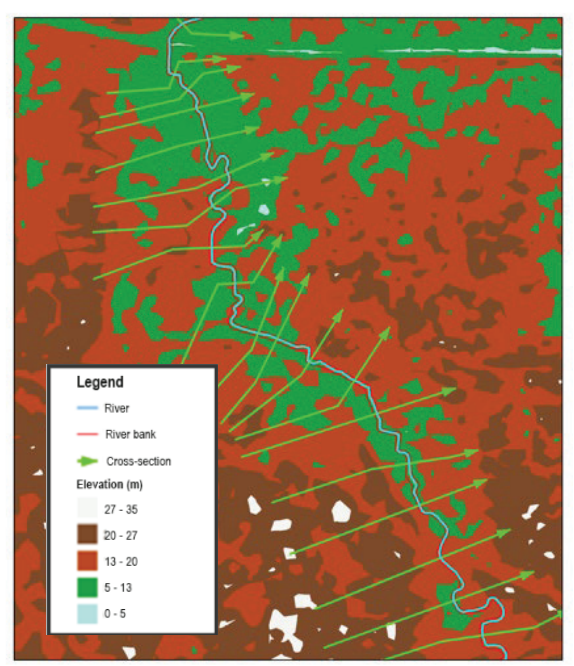

Fig. 6. Cross-section of study area.

\section{Results}

Calculation of flood discharge is a calculation with hydrological factors such as rainfall and the characteristics of the river segment. Characteristics to determine the curve number $(\mathrm{CN})$ in the calculation of flood discharge using SCS-CN method in the form of topography, land use, and soil type. The output from the calculation of flood discharge is used to delineate the flood inundation. Rainfall data based on BMKG from data from the Halim Perdanakusumah Rainfall Station on February 19, 2021 at 15:00 WIB is $160 \mathrm{~mm}$ /day.

$\mathrm{CN}$ value is obtained based on land use and soil hydrological groups. The type of land use in the upstream area is a built-up urban area with a subtype of open space, namely golf courses with grass cover exceeding $75 \%$. Soil characteristics in the upper stream and study area determine the class of soil hydrology. Soil belongs to group D which tends to have saturated hydraulic conductivity from the least transmissive layer, the depth of the impermeable layer is in the range of 50$100 \mathrm{~m}$. The hydrological condition of class D soil has a high potential for runoff when wet conditions with a slow infiltration rate, therefore making it an area that is easily flooded. Class D soils have between $40 \%$ clay and $<50 \%$ sand and have textures of loam, silt loam, sandy loam, loamy loam, and silty loam. By looking at the curve table, the $\mathrm{CN}$ used is 80 , seen on Table 3 .

Soil retention potential or $S$ is the capacity or ability of a river to sustain extreme rainfall. The runoff will remain zero until the accumulated rainfall exceeds the initial abstraction $(I a)$. From the manual calculations, the maximum flood discharge results for some time when the flood is in progress is $102.98 \mathrm{~m}^{3} / \mathrm{s}$.

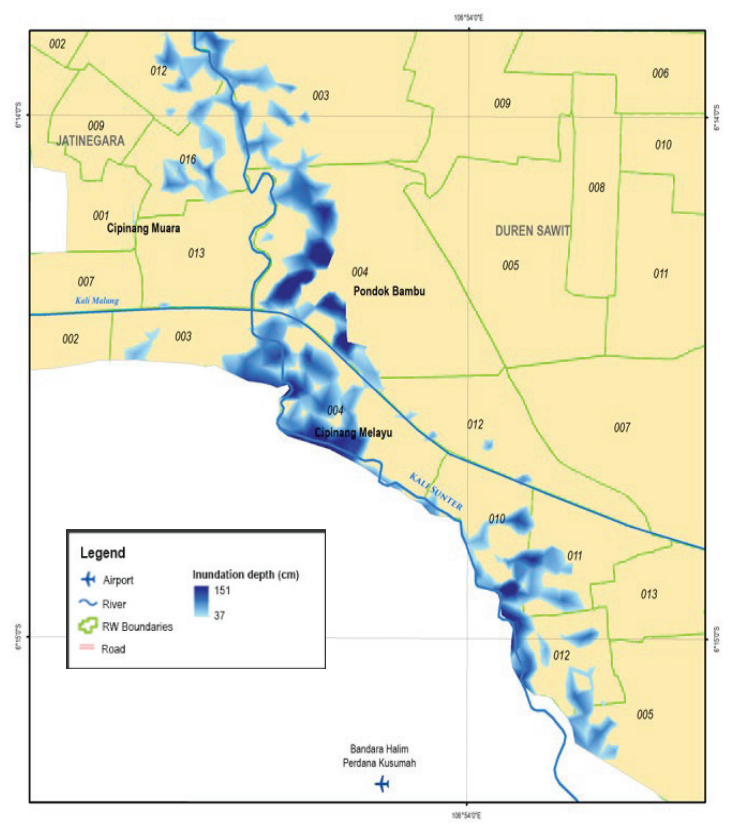

Fig. 7. Flood Inundation Map. 
Table 3. Curve Number on Technical Release (TR-55) USDA.

\begin{tabular}{|l|c|c|c|c|c|}
\hline \multicolumn{1}{|c|}{ Description } & \multicolumn{5}{|c|}{ Curve Numbers for } \\
\hline \multicolumn{1}{|c|}{ Land cover type and hydrologic condition } & A & B & C & D \\
\hline \multicolumn{1}{|c|}{ Fully-developed urban areas } \\
\hline $\begin{array}{l}\text { Open spaces (lawns, parks, golf courses, cemeteries, } \\
\text { others): }\end{array}$ & & & & & \\
\hline Poor conditions (grass cover $<50 \%$ ) & 68 & 79 & 86 & 89 \\
\hline Moderate conditions (grass cover 50\% - 75\%) & 49 & 69 & 79 & 84 \\
\hline Good condition (grass cover $>75 \%$ ) & 39 & 61 & 74 & 80 \\
\hline
\end{tabular}

From the HEC-RAS modeling, it is known that the total flow area based on the cross section is $143.63 \mathrm{~m}^{2}$ on the left side of the river body (overbank flow) and $12.64 \mathrm{~m}^{2}$ on the right. The total flow rate is $102.93 \mathrm{~m}^{3} / \mathrm{s}$ with the flow in the puddle on the left is $98.75 \mathrm{~m}^{3} / \mathrm{s}$ and $4.18 \mathrm{~m}^{3} / \mathrm{s}$ on the right. The surface width of the inundated cross-section on average is $164.20 \mathrm{~m}$. The height of the water surface calculated from the energy equation is $14.96 \mathrm{~m}$ and the critical water level is 14.02 $\mathrm{m}$. The average total flow velocity based on the cross section is $0.66 \mathrm{~m} / \mathrm{s}$. The transport discharge is $4,570 \mathrm{~m}^{3} / \mathrm{s}$ with the main flow length of $428.56 \mathrm{~m}$.

The dominant flood inundation is on the left side of the river body which includes Cipinang Melayu and Cipinang Muara Sub-districts. After normalization happened in 2011, the river segment that separates the Cipinang Muara from Pondok Bambu is higher than the housing in the eastern part or the settlements around the Pondok Bambu. The maximum depth is $1.51 \mathrm{~m}$ in the main stream, while the maximum inundation depth is $1.11 \mathrm{~m}$ and the minimum depth is $0.37 \mathrm{~m}$.

Characteristics of flood-affected areas are determined based on land use. The large number of residential types of land use indicates the high population of a village and the number of buildings in the coverage area of the study. With a total of 497 residential buildings, Pondok Bambu is the sub-district with the most types of residential buildings when compared to the other two. In detail, the types of land use affected by flooding in the scale of Rukun Warga (RW) or local community will be discussed.

The level of flood hazard is determined by the depth of water inundation at a location or land use with a high population. The same water level in residential areas with open land has a different level of danger. Settlements are more vulnerable to flooding than open land because the safety and welfare of the community is threatened. Although Kalimalang River near Cipinang Melayu area and BKT was not affiliated with the cause of the flood that happened. The reason is because the canal and Kalimalang flow condition was stable and there was no discharge. BKT acted as an outlet for the flood near Cipinang Indah Residence.

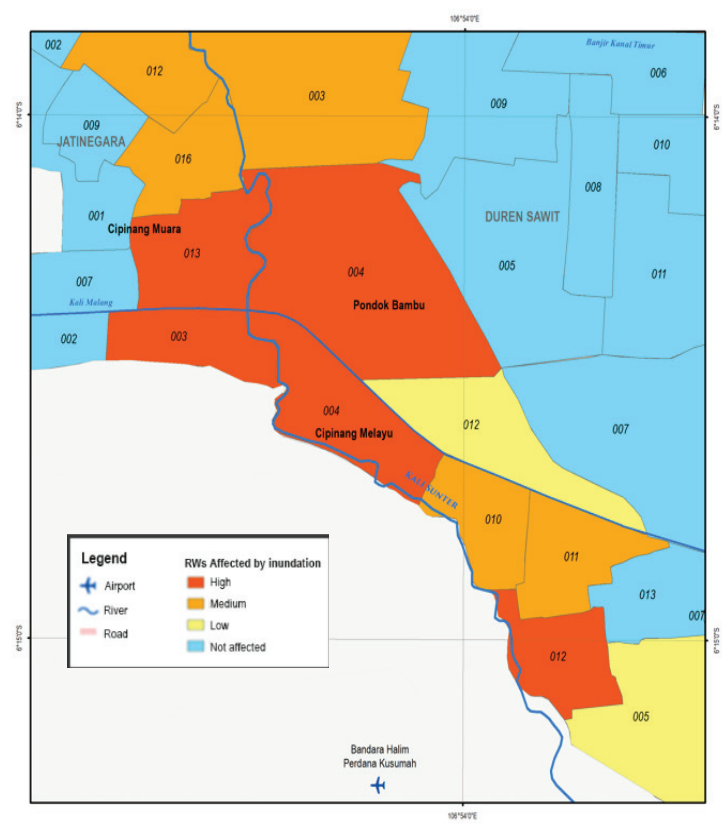

Fig. 8. Flood Inundation Map per RW.

The total of 10 RWs are passed by or directly adjacent to the Sunter River, namely RW 012, 013, 016 from Cipinang Muara, RW 003, 004 from Pondok Bambu, and RW 003, 004, 005, 010, 012 from Cipinang Melayu. From the result of overlaying the administrative map with the flood inundation map, we get a map of the RW affected by flooding with levels, as shown in Figure 8 .

Pondok Bambu Village was hit by floods in 2 RWs, namely RW 003 and RW 004. The height of inundation in both RWs varied, at RW 003 it was $31-70 \mathrm{~cm}$ high and in RW 004 it was $151 \mathrm{~cm}$. Types of land use affected in RW 003 are houses of very small type or size and medium houses, shop houses, green space and open space, and city parks. The type of house that dominates in RW 003 is a medium-sized house located in Cipinang Indah Residence, and RW 003 has green land and large vacant land, both on the banks of the river and around the housing estate. In contrast to RW 004, the flood inundation has an impact on public facilities compared to houses or housing. There are several types of housing in RW 004 with small types. The types of land use affected in RW 004 are as follows.

Access from the Kali Malang Channel Inspection Road to Jalan Cipinang Indah Raya II goes downhill. On the border between RW 003 and RW 004, there is green land and vacant land which is quite large and is located lower than buildings and roads, so that puddles are not trapped on concrete land and are more easily absorbed into the ground. There is an upper secondary education service building located on the edge of the river, but the school is not affected because the location of the 
building is higher than the road, so that runoff water does not inundate the school, but goes to a green open land located on Jalan Kutilang. Small-type houses located on the banks of the river or the border between Kelurahan Pondok Bambu and Kelurahan Cipinang Muara are higher than road level, so they have bridge access to it.

RW 012 and RW 016 are dominated by housing of Villa Cipinang Indah which has various types of housing, ranging from small, medium, to large types. Meanwhile, in RW 013, most of the houses affected are small in size, namely houses on the banks of the river, bordering the Pondok Bambu Village.

The most affected areas are the one in the lowest slopes, such as RW 004, Cipinang Melayu, areas near Mall Cipinang Indah, and Cipinang Indah Residence near East Flood Canal or Banjir Kanal Timur (BKT). According to rescuer team, it reached 90-150 cm depth at its peak and the maximum depth was calculated to be $151 \mathrm{~cm}$. The flood mostly affected houses and other infrastructures, such as commercial industries and public facilities.

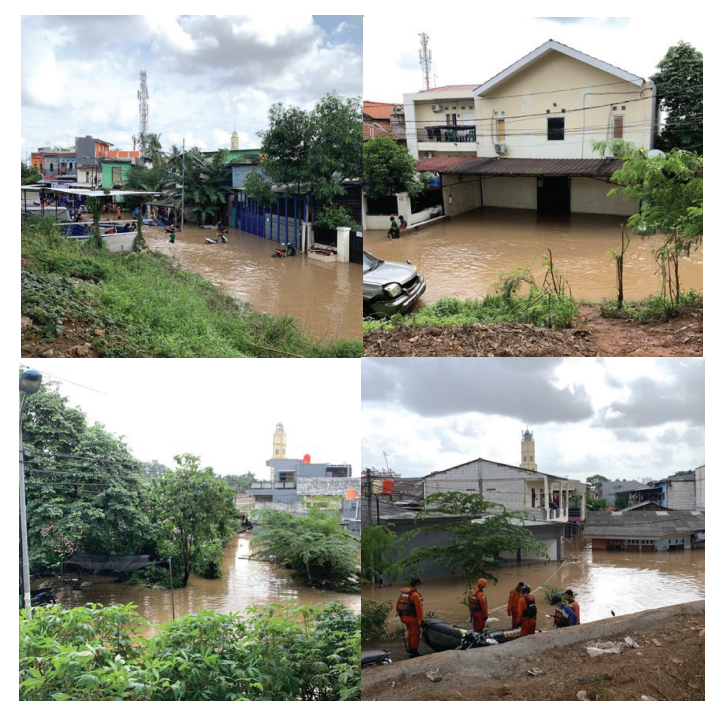

Fig 9. Flood condition in RW. 04, Cipinang Melayu.

\section{Conclusions}

The distribution of the highest flood hazard area is in RW 004, Cipinang Melayu Village. Among the three sub-districts, Cipinang Melayu is also the one with the largest inundation. In this RW, there are several types of land use, such as residential, green land, vacant land, houses of worship, and higher education. The dominance of land use is small and medium-sized houses. In RW 012, 013, and 016 Kelurahan Cipinang Muara, the inundated areas are categorized as low, with the affected buildings in the form of houses and green land. Meanwhile, RW 003 and RW 004 in Pondok Bambu Village have a moderate to high level of danger.
Characteristically, the western part, such as Cipinang Muara and part of the Cipinang Melayu Village, is higher than the eastern part, such as Pondok Bambu. Green land is useful in water infiltration, so the wider the green land, the more water will be absorbed into the soil, so it does not cause inundation. A large vacant land is located in RW 004 Pondok Bambu Village, so water will only inundate the land and reduce the potential for water to inundate buildings or other land uses. The types of buildings and dwellings in the Cipinang Muara Village housing estates tend to be more organized and relatively medium to large in size and have one or two floors. While the types of housing in the Cipinang Melayu Village tend to be compact and small to medium in size, but the majority have two floors.

Extreme rainfall which causes rivers to overflow is the main cause of flooding in the Cipinang Melayu Village and surrounding areas. HEC-RAS is useful as an effective hydraulic modeling tool so it can be used for real-time modeling. HEC-GeoRAS is an ArcGIS integrated extension for hydraulic modeling with available georeferenced data. Flood inundation mapping is important for mitigation purposes and the results can be informed quickly.

With limited data and time, this study only reviews the physical aspects, starting from flood hazard modeling to analyzing the characteristics of the affected area. The results of this study can be used as a reference in the development of research on the social characteristics and resilience of the affected community if there are adequate data related to the loss of flood events.

This research is one of the requirements for graduation in the Department of Geography, Faculty of Mathematic and Natural Science, University of Indonesia. The authors would like to thank the Directorate of Research and Community Engagement (DPRM) University Indonesia for the research funding program Publikasi Terindeks Internasional (PUTI) Saintekes in 2020 No. NKB-4876/UN2.RST/HKP.05.00/2020

\section{References}

1. A. Cook, V. Merwade, J. Hydro. 377(1-2), 131-142 (2009)

2. F. Hajibayov, B. Ozkul, F. Terzi, Geographical Information Science Research- UK (GISRUK) April 2017, University of Manchester, UK (2017)

3. A. Bannari, G. Kadhem, IGARSS 2019, in IEEE International Geoscience and Remote Sensing Symposium, 28 July-2 Aug. 2019, Yokohama, Japan (2019)

4. A. Pathan, P. Agnihotri, Intl. J Recent Tech. Eng. 8 (1), 1410-1417, (2019)

5. I. Susanti, Improving Lesson Learnt in Disaster Management, in MATEC Web of Conferences 229, International Conference on Disaster Management, ICDM, 2-4 May 2018, Padang, Indonesia (2018)

6. A. El-Naqa, M. Jaber, J Civ. Env. Eng. 8 (5), (2018) 
7. B. Takhur, R. Parajuli, A. Kalra, S. Ahmad, R. Gupta, World Environmental and Water Resources Congress, 240-251, California, USA (2017)

8. Y. İcaga, E. Tas, M. Kilit, Acta Geobalcanica 2(2), 111-118 (2016)

9. H.Z. Abidin, H. Andreas, I. Gumilar, I.R. Wibowo, Changes in Flood Risk and Perception in Catchments and Cities in Proceeding IAHS, 370, 15-20, IUGG, 22 June-2 July 2015, Prague, Czech Republic (2015)

10. H. Takagi, M. Esteban, T. Mikami, D Fujii, U. Climate 17, 135-145 (2016)

11. Z. Liu, L. Cuo, Q. Li, X. Liu, X. Ma, L. Liang, J. Ding, Water 12 (4), 1198 (2020)

12. I.R. Moe, S. Kure, N.F. Januriyadi, M. Farid, K. Udo, S. Kazama, S. Koshimura, Hydro. Rsch. Letters 11 (2), 99-105 (2017)

13. E.K. Ovilia, E. Primadianti, D Yatmadi, Const. Mat. J. 2 (3), 219-228 (2020)

14. M. Tambunan. Strengthening Sustainbility Development, in MATEC Web of Conferences 229, in International Conference on Disaster Management, ICDM, 2-4 May 2018, Padang, Indonesia (2018)

15. UN World Population Prospects, Jakarta, Indonesia Metro Area Population 1950-2021. www.macrotrends.net. Retrieved 2021-04-15.

16. C.T. Ackerman, GIS Tools for Support of HECRAS using ArcGIS ${ }^{\circledR}$, HEC-GeoRAS User's Manual (US Army Engineers-HEC, California, 2011)

17. S.K. Mishra, V. Singh, Soil Conservation Service Curve Number (SCS-CN) Methodology (2003)

18. E. Kusratmoko, K. Marko, M. Elfeki, J. Geo. Env. Earth Sci. Intl. 5 (3), 1-10 (2016) 